NBER WORKING PAPER SERIES

\title{
WHY PARENTS PLAY FAVORITES: \\ EXPLANATIONS FOR UNEQUAL BEQUESTS
}

\author{
Audrey Light \\ Kathleen McGarry \\ Working Paper 9745 \\ http://www.nber.org/papers/w9745

\section{NATIONAL BUREAU OF ECONOMIC RESEARCH 1050 Massachusetts Avenue Cambridge, MA 02138}

May 2003

We thank Cheryl Segrist and Pat Rhoton of the Center for Human Resource Research for assistance with the data and Enrica Croda for helpful comments. McGarry gratefully acknowledges financial support from the National Bureau of Economic Research. The views expressed herein are those of the authors and not necessarily those of the National Bureau of Economic Research.

(C)2003 by Audrey Light and Kathleen McGarry. All rights reserved. Short sections of text not to exceed two paragraphs, may be quoted without explicit permission provided that full credit including $(\subset)$ notice, is given to the source. 
Why Parents Play Favorites: Explanations for Unequal Bequests

Audrey Light and Kathleen McGarry

NBER Working Paper No. 9745

May 2003

JEL No. D1

\begin{abstract}
$\underline{\text { ABSTRACT }}$
Economists have invested a great deal of effort in trying to understand the motivation for family transfers, yet recent empirical work testing the seemingly appealing models of altruism and exchange has led to decidedly mixed results. A major stumbling block has been the lack of adequate data. We take a fresh look at the issue using responses to an innovative survey question that directly asks mother about the planned division of their estates. We find that both altruism and exchange are frequently offered as explanations of behavior and are of nearly equal importance. Furthermore, the explanations are consistent with observable characteristics of the mother, lending support to the validity of the question. We also find that among step or adopted families, genetic ties play an important role. Because motivating factors appear to differ across families the lack of a consensus among previous researchers about motives ought not to be surprising.
\end{abstract}

Audrey Light

Department of Economics

Ohio State University

\author{
Kathleen McGarry \\ Department of Economics \\ University of California, Los Angeles \\ 405 Hilgard Avenue \\ Los Angeles, CA 90095-1477 \\ and NBER \\ mcgarry@ucla.edu
}




\section{Introduction}

Parents often appear to "play favorites" when distributing financial resources among their adult children. Recent studies indicate in any given year, approximately $75 \%$ of parents who make inter vivos transfers to their children, give unequal amounts. Even when making bequests — where equal division is the norm —as many as $20 \%$ of parents treat their children unequally. ${ }^{1}$ This evidence is consistent with a number of models of optimizing behavior, each of which predicts parents will favor certain children in allocating resources. The altruism model (Barro, 1974; Becker, 1974; Becker and Tomes, 1979) assumes parents want to equalize marginal utilities across family members - a goal they achieve by giving the largest transfers to their least well-off children. The exchange model (Bernheim, Shleifer and Summers, 1985; Cox, 1987; Cox and Rank, 1992) assumes parental transfers are payments for such child-provided services as affection and household help; because the price of these services varies with child income, the model predicts an unequal distribution of transfers. Cox (in press) argues that parents may make transfers to promote the survival of their genes. If parents are driven by evolutionary motives, they should favor biological children over adopted and step children, and they should give more to children who produce (or are likely to produce) grandchildren.

Efforts to determine which motive dominates parental decisions to treat their children unequally have met with decidedly mixed results (e.g., Altonji, Hayashi, and Kotlikoff, 1992, 1997; Perozek, 1998). Moreover, all three theoretical models fail decisively when faced with the prevalence of equal bequests. This gap between theory and evidence has prompted researchers to develop alternative models that justify the equal distribution of transfers (Andreoni, 1989) or explain why parents differentiate among their children with inter vivos transfers but not bequests (Bernheim and Severinov, 2000; McGarry, 1999; Wilhelm, 1996).

While these additional theoretical insights may prove useful, it is apparent that richer data are needed as well. Tests of the altruism, exchange, and evolutionary models would gain considerable power if data were available on lifetime incomes and transfers. Parents may alter their patterns of giving over time if, for example, their children's economic circumstances change or if there is "lumpiness" in the flow of transfers. Such intertemporal fluctuations may be consistent with the standard models, yet they could lead researchers to misinterpret parental motives when examining cross-sectional snapshots of transfer allocations. It is unlikely that we will ever succeed in measuring cumulative, lifetime transfers, but the

\footnotetext{
${ }^{1}$ The transfer figure is from an analysis of data from the Asset and Health Dynamic Study reported in McGarry and Schoeni (1997). Using the same data source, McGarry (1999) finds that $17 \%$ of parents aged 70 and over who name children in a will intend to divide their estates unequally. Using federal estate tax data, Wilhelm (1996) finds that $23 \%$ of estates are divided unequally, meaning not all children receive a bequest within $2 \%$ of the family mean.
} 
advent of panel data on parent-to-child transfers presents one promising, new avenue for empirical research (Hochguertel and Ohlsson, 2000; McGarry, 2000).

An alternative approach is to collect new and different data that will allow researchers to tease uncover motives with cross-sectional observations. In the current study, we take the latter approach and draw on newly available donor-reported explanations for the allocation of transfers. In 1999, respondents in the National Longitudinal Surveys (NLS) of Young Women and Mature Women reported detailed information about each of their children, recent transfers between themselves and their children, and their intended bequests. One feature of the data is particularly novel: mothers who report that they intend to divide their estates unequally among their children were asked to explain the reason for their intentions. While only $8 \%$ of mothers fall into the "unequal bequests" category, their verbatim responses are the first direct evidence of parental motives for allocating resources among their children. ${ }^{2}$

In analyzing these NLS data, we begin by asking whether mothers' self-reported explanations for intended unequal bequests conform to the ideas of altruism, exchange, and evolution. That is, we look for responses along the lines of "I plan to give more to my poor children," "I plan to give more to the child who takes care of me," and "I plan to favor my biological children." Remarkably, the majority of verbatim responses fit reasonably neatly into one of these three categories. Among mothers who intend to divide their estates unequally, $25 \%$ provide an explanation that conforms to altruistic behavior, $25 \%$ give an exchange-related response, and $10 \%$ refer to the biological status of their children. The remaining mothers are evenly divided between those who, based on their explanation, appear to intend an equal division of their estate (and who may have misunderstood the question), and those who give a "nonexplanation" (e.g., "It's nobody's business why"). No mother provides an explicit explanation that fails to conform to motives of altruism, exchange, or evolution.

We also find that mothers' observed characteristics are correlated with their bequest intentions in a manner largely consistent with all three competing theories. The probability that a mother intends unequal bequests is significantly higher if she is in poor health (which may reflect her need for children's "services" and willingness to pay), if she has nonbiological children, and if her children's predicted incomes are especially different from each other (which suggests she intends to favor the least affluent). Moreover, these observable proxies for altruistic, exchange, and evolutionary motives prove to be correlated with the self-reported explanations. We find that mothers in poor health are more likely than

\footnotetext{
${ }^{2}$ Although economists have traditionally been skeptical about the usefulness of self-reported explanations, a growing body of research is finding that they can provide important insights not obtainable with standard methods (c.f. Manski, 1990; Laitner and Juster, 1996; Dominitz, 1998; Hurd and McGarry, 2002). Basset and Lumsdaine (2003) cite the growing list of surveys collecting expectations data as evidence of a "resurgent interest" in these
} 
other mothers to provide an exchange-related explanation for their intended unequal bequests. Similarly, mothers with nonbiological children often refer to their children's biological status in explaining their intended bequests. We find only one anomalous pattern in the data, in that mothers whose children's predicted incomes differ greatly are not more likely than others to give an altruism-related explanation.

Finally, we compare mothers' intended bequest allocations with their actual patterns of inter vivos transfers to see if the same motives might drive both forms of giving. The data reveal that $77 \%$ of mothers who intend to make equal bequests, distribute inter vivos transfers unequally among their children. While relatively few mothers intend to make unequal bequests, these mothers are more likely than others to make equal inter vivos transfers; this negative correlation between unequal bequests and unequal transfers holds unconditionally, and it holds in a multivariate model of the probability of unequal transfers. In short, there is a pronounced tendency for mothers to treat their children equally at one point in their lives and unequally at another.

Our results suggest that motives for intra-family transfers differ across mothers. Altruism, exchange, and a preference for biological children — which, as we argue below, may reflect altruism or exchange as much as genetic links - all appear to be empirically important reasons for distributing resources unequally among children. We also find that motives vary over time for most mothers so that patterns of giving during life may differ from those for bequests. In light of these findings, we are not surprised that researchers have failed to form a consensus in support of a single theoretical model.

In the next section, we provide additional details on the alternative models of intra-family transfers and previous efforts to distinguish between them. In section 3 we describe the data. In section 4 we analyze the intended bequest decisions of the mothers in our sample. We model the probability that mothers intend to divide their estates unequally among their children, and we analyze their self-reported explanations for unequal bequests to shed additional light on the motives behind their intentions. In section 5 we compare the intended division of bequests with the actual division of inter vivos transfers to determine whether mothers' transfer behavior is intertemporally consistent. We offer concluding comments in section 6 .

\section{Background}

The three competing motives that we explore-altruism, exchange, and evolution-offer distinct explanations for why parents distinguish among their children in making transfers. The goal of our empirical analysis is to learn the extent to which allocation decisions reported by mothers in the NLS

types of data (page 2). We view the data analyzed here as an important supplement to reports on actual giving that have been analyzed in the past. 
conform to the alternative explanations. We begin our discussion with an overview of each model and a summary of the existing empirical evidence on patterns of intra-family transfers.

The altruism model (Becker, 1974; Barro, 1974; Becker and Tomes, 1979) assumes a parent obtains utility from her own consumption $\left(C_{p}\right)$ and the utility level of each child $k\left(V\left(C_{k}\right)\right)$. Assuming a two-child family for simplicity $(k=1,2)$, the parental utility function takes the form $U_{p}=U\left(C_{p}, V\left(C_{1}\right), V\left(C_{2}\right)\right)$. The parent must decide how to allocate resources between her own consumption and each child's consumption. At the optimal interior solution, the marginal utility of a dollar transferred to each child and the marginal utility of a dollar spent on own consumption are all equal. Because the marginal utility of a transfer depends on the child's pre-transfer income, a key prediction of the model is that child income is negatively correlated with parent-to-child transfer amounts.

In the exchange model (Bernheim, Shleifer and Summers, 1985; Cox and Rank, 1992) the parental utility function is $U_{p}=U\left(C_{p}, S\right)$, where $S$ represents services provide by the children. Services can be actual care and assistance, attention paid to the parent, or even behavior that is valued by the parent. Parents must pay for these services — and because the price depends on the value of the child's time, the parent is more likely to purchase services from a low-income child because the cost of that child's time is relatively low. The exchange model thus predicts that the probability of a parent-to-child transfer is negatively related to child income. However, the model makes no prediction about the correlation between transfer amounts and child income. The parent is expected to purchase fewer services at a higher "per unit" price from her high-income child; the total cost of those services (which is the transfer amount) depends on price elasticities of child-specific supply and parent-specific demand for child services.

Cox (in press) argues that transfers may arise from an innate desire to aid the survival of ones' genes. As a result, adopted children and stepchildren should receive less than biological children. Evolutionary theory also predicts that the sex of both parent and child may play a role. Because a mother is always certain that a child she gave birth to is her biological child, she will be willing to transfer resources to the child. A father, however, might harbor doubt about his genetic relationship to the child and be less generous. Similarly, a parent might give more generously to a daughter than to a son because the daughter's offspring are certain to be genetic descendents. Whether parents favor children with (biological) children of their own when allocating resources is less clear. On one hand, parents may reward children who have already produced genetic heirs. On the other hand, they may give relatively 
large amounts to childless children to assist with the eventual cost of raising a child or simply to "motivate" them to produce grandchildren (Cox and Stark, 1999).

From an empirical standpoint, it is exceedingly difficult to distinguish between these competing models. For example, a parent who favors her biological children in allocating resources may be driven by an evolutionary motive or she may be behaving altruistically if her stepchildren or adopted children receive transfers from their birth parents. ${ }^{3}$ Alternatively, an exchange-motivated parent may give more to her biological children if they provide services more efficiently than nonbiological children, perhaps because they have known her longer and are more familiar with her preferences. Similarly, parents may favor daughters not because of an evolutionary motive, but because daughters provide services at a lower cost than do sons. ${ }^{4}$ The exchange model is particularly difficult to reject as an explanation for behavior because it is consistent with either a positive or negative relationship between transfer amounts and children's income, and because transfers need not coincide temporally with the provision of purchased service.

Given the inherent difficulty of distinguishing between models, it is unsurprising that the empirical literature has been unable to find consistent support for any particular hypothesis. Much of the difficulty reflects the lack of high-quality data and corresponding shortage of rigorous tests of alternative hypotheses. For example, several analysts use probate records and other specialized sources to examine the actual division of deceased parents' estates (Menchik 1980, 1988; Tomes, 1981, 1988; Wilhelm, 1996), but questions arise about the applicability of their findings to the general population. Studies of estate division also typically lack information on inter vivos giving, while studies of inter vivos transfers lack data on the division of the eventual estate. ${ }^{5}$

Despite data limitations, two empirical regularities have emerged. First, inter vivos transfers generally prove to be negatively related to children's income (Altonji, Hayashi, and Kotlikoff, 1997; Cox and Rank, 1992; Dunn and Phillips, 1997; Hochguertel and Ohlsson, 2000; McGarry and Schoeni, 1995, 1997); this evidence is consistent with both the altruism and exchange models. Second, most data sources suggest that estates are divided equally among children in the overwhelming majority of cases (Dunn and

\footnotetext{
${ }^{3}$ The well-being of the children can be viewed as a public good, with both the mother and step-mother choosing how much to transfer to the child. Schoeni (2001) investigates such behavior in a similar context, where young married couples receive support from two sets of parents.

${ }^{4}$ Coward and Dwyer (1990) and Stoller, Forster, and Duniho (1992), among others, find that daughters are more likely than sons to care for their parents.

${ }^{5}$ An advantage of our study is that we have data for the actual division of inter vivos transfers as well as intended bequests. The same is true of Dunn and Phillips (1997) and McGarry (1999), both of which use data from the Asset and Health Dynamics Study.
} 
Phillips, 1997; McGarry, 1999; Menchik, 1980, 1988; Wilhelm, 1996). ${ }^{6}$ These patterns are difficult to reconcile with the models described above, and suggest that single, point-in-time observations on parental giving invariably fail to tell the entire story. Because ideal data on lifetime transfers and incomes are unavailable (and, in all likelihood, will never become available), we turn instead to parents' self-reported descriptions of their motives for giving.

\section{Data}

\subsection{Samples}

Our data are from the National Longitudinal Surveys of Mature Women and Young Women. The NLS of Mature Women began in 1967 with a sample of 5,083 women born in 1922-37. The Young Women survey began in 1968 with a sample of 5,159 women born in 1943-53. Each original sample is representative of the civilian, non-institutionalized population of women who lived in the U.S. when the survey began and who belonged to the relevant birth cohorts; each sample also includes an over-sample of black women.

We use data from the 1999 interview because an extensive module on transfers between respondents and their children was fielded that year. Respondents were asked detailed questions about the characteristics of each of their children, money and time transfers to and from each child, and their intended bequests. We have identical information for Young Woman and Mature Woman respondents so we pool the two cohorts for our entire analysis. ${ }^{7}$ By this point in the survey, attrition reduced the sample to 2,467 Mature Women respondents and 2,900 Young Women respondents.

We construct two different samples to analyze mothers' division of bequests and inter vivos transfers among their children; our selection criteria are detailed in appendix table A. From the 5,367 Mature Women and Young Women respondents interviewed in 1999, we begin by selecting 3,491 women with at least two children age 18 or over. Next, we exclude 1,682 mothers who report having no will, 111 for whom the existence of a will is unknown, and another 60 who exclude their children from their will. Our goal is to keep only those mothers whose preferences regarding estate division are known. We eliminate mothers who exclude children from their will because it is unclear if they intend to divide resources equally by giving nothing to each child, or if they would prefer unequal division involving

\footnotetext{
${ }^{6}$ Laitner and Ohlsson $(2001)$ and Tomes $(1981,1988)$ present evidence that estates are divided unequally among children, although Tomes's findings have been refuted by Menchik (1988).

${ }^{7}$ From 1995 onward, the same survey instrument was used for the two cohorts and the fielding effort was conducted simultaneously. The 1999 interview is the $19^{\text {th }}$ for the Mature Women and $20^{\text {th }}$ for the Young Women.
} 
negative transfers. Similarly, we eliminate women without wills because their intentions are ambiguous. ${ }^{8}$ Finally, we eliminate 20 mothers who do not indicate whether they intend to divide their estate equally among their children. The 1,618 remaining mothers form our "bequest sample."

We are forced to pare the sample down further to analyze the distribution of inter vivos transfers. While all respondents with children are asked about their intended bequests, only a subset are asked about transfers to children in the last year. ${ }^{9}$ Among the 1,618 women in our bequest sample, 452 do not report inter vivos transfer information for any of their children. We eliminate another 311 women who reveal that they made no transfers (of cash, loans, gifts, or financial assistance) to any of their children in the last year. As with bequests, it is unclear whether these mothers prefer to treat their children equally, or whether they prefer an unequal division of negative (child-to-mother) transfers. ${ }^{10}$ These additional selection rules produce a "transfers sample" of 855 mothers.

\subsection{Explanatory variables}

Table 1 reports summary statistics for the explanatory variables used to model the probabilities of unequal bequests and unequal inter vivos transfers. We summarize these variables for the bequest and transfers samples, as well as for a sample of all women with at least two adult children. We use this larger sample as a benchmark to judge the characteristics along which the bequest and transfers samples are selected.

Our model includes measures of annual family income, total assets, home ownership, and mothers' highest grade completed. These variables include husbands' resources, where applicable, and are intended to control for heterogeneity in the resources available for transfer. We also include standard, demographic controls for mothers' age, race, and marital status. To investigate exchange motives for mother-to-child transfers, we control for each mother's self-reported health status and whether she receives help from any of her children. The "poor/fair health" indicator equals one for women who report that compared to other women their age, their health is in the bottom two of four

\footnotetext{
${ }^{8}$ In principle, mothers who wish to divide their estate equally among their children may intentionally forego writing a will because they expect state law to mandate an equal division. Rather than make that assumption, we opt to eliminate respondents without a will.

${ }^{9}$ To reduce respondent burden, women with no coresident children and more than five non-coresident children are not asked child-specific transfers questions The remaining mothers answer child-specific questions for up to five of their children; those with more than five children answer the questions for their coresident children only. The child count includes biological, adopted, and step children who are age 19 or older (or age 14-18 and married or with children), and who are named by the mother during a child enumeration conducted at the start of the transfers portion of the 1999 interview.

${ }^{10}$ We have data on child-to-mother transfers, but they do not necessarily reflect mothers' desired (negative) transfers because mothers cannot always extract as much as they wish from their children. We assume mothers who give unequally to their children attain their desired (unequal) distribution, even if they are constrained in the amounts transferred.
} 
categories (poor, fair, good, excellent). The "receives help" variable equals one for women who report receiving help with personal care, household chores, or errands from any of their children during the last year.

The remaining variables measure the characteristics of each woman's children-especially the differences in children's circumstances that are likely to be related to mothers' unequal transfer allocations. We control for the total number of children as well as the sex composition (whether she has both boys and girls) because the evolutionary model predicts greater transfers to daughters due to the more certain genetic ties. Furthermore, previous research consistently reveals that daughters are more likely than sons to provide care, so the "mixed sex" indicator may also reveal patterns consistent with exchange models. In light of the evolutionary model's prediction that parents distinguish between biological, adopted, and step children in allocating resources, we include these child characteristics as well. We also control for whether the woman has coresident children (who may be needier than others and/or provide services to the mother) and whether her children are "mixed" in having children of their own (i.e., whether some, as opposed to all or none, of her children have children).

In light of the altruism model's prediction that parents make larger transfers to relatively lowincome children, it is important that we include a measure of child well-being. NLS respondents are not asked to report their children's income directly, so we construct a measure of predicted income based on observable characteristics. We believe predicted income is a better control than current income because intended bequests are likely to be determined with a long-term, "smoothed" view of children's relative needs. We predict each child's family income using estimated parameters from income models that we fit to data from the 2000 annual demographic (March) supplement of the Current Population Survey. ${ }^{11}$ After predicting the income of each child we compute the coefficient of variation for each woman, which is the within-family standard deviation as a percent of the within-family mean.

Table 1 reveals that among mothers in the bequest sample, the average age is 62 (the range is 45 80 ), $70 \%$ are married, $18 \%$ are widowed, and $12 \%$ are divorced. ${ }^{12}$ Relative to the benchmark sample of all women with at least two children, women in the bequest sample are better off financially: their average income is $\$ 41,300$ ( $v s . \$ 35,820$ in the full sample), the average value of their bequeathable assets,

\footnotetext{
${ }^{11}$ Our sample consists of all CPS respondents in the same age range as the children of our NLS mothers. We estimate separate income models for men and women using as regressors a constant, a quartic in age, seven dummy variables indicating schooling attainment (degrees earned), and dummy variables indicating race, marital status, number of children, whether the individual resides with his/her parents (or spouse's parents), and whether the individual owns a home.

${ }^{12}$ Only six mothers in the bequest sample and three in the transfers sample are never married. We combine them with the married women throughout our analysis; our estimates are invariant to how we treat these cases.
} 
including housing, is $\$ 332,100$ (vs. $\$ 225,500$ ) and 92\% own a home (vs. 81\%). They are more likely to be white ( $89 \%$ vs. $76 \%$ ) and married (70\% vs. 62\%), slightly less likely to be in poor health (20\%vs. $27 \%$ ), and they have slightly fewer children. These patterns suggest that mothers who have a will—and who, therefore, appear in the bequest sample - have more resources to distribute to their children than do mothers in general.

The right-most columns in table 1 report the summary statistics for the smaller sample of women who made transfers to their children in the last year. Not surprisingly, women actively making inter vivos transfers have somewhat greater income and asset levels than do the larger samples of women. They also have slightly fewer children than women in the bequest sample (3.1 vs. 3.4), which reflects the fact that most mothers with more than five children are excluded from our transfers sample because of the survey design (see section 3.1).

\section{Intended bequests}

We begin our analysis by modeling the probability that mothers intend to make unequal bequests to their children. In section 4.1, we use as our "unequal bequest" indicator each woman's direct response to the question, "Will your estate be divided equally among your children?"13 Among the 1,618 mothers in our bequest sample, 1,490 (92.1\%) say "yes" and the remaining 128 say "no." We model the probability of answering "no" as a function of the explanatory variables defined in the proceeding section. This exercise reveals whether observed characteristics that are consistent with exchange motives (e.g., poor health), altruism motives (e.g., a high coefficient of variation of children's income) and evolutionary motives (e.g., having both biological and nonbiological children) are correlated with women's intentions to divide their estate unequally.

In section 4.2, we make use of verbatim responses to the question, "Why will your estate not be divided equally among your children?" This question is asked of the 128 mothers who answer "no" to the equal/unequal question given in the proceeding paragraph. We use the stated reasons to experiment with alternative definitions of "unequal." In addition, we assess the extent to which women's reasons are consistent with exchange, altruism, and evolutionary motives.

\subsection{Probability of equal bequests}

Table 2 presents logit estimates of the probability that mothers intend to distribute their estates unequally among their children, based on "yes/no" responses to the initial question about estate division.

\footnotetext{
${ }^{13}$ For married respondents who report that they are leaving everything to their husband, the phrase "if your husband dies before you or with you" is added to the question.
} 
Statistically significant effects are identified with boldface type. The estimates reveal that the probability of intending unequal bequests does not differ by financial status. The estimated coefficients for both income and wealth are statistically indistinguishable from zero. Similarly, the coefficients for indicators of home ownership and mother's schooling levels are estimated very imprecisely. Instead of financial characteristics, factors relating to health and child characteristics are important.

Our indicator of poor maternal health plays an important role. Being in fair or poor health is associated with a two percentage point increase in the probability of unequal intended division for mothers with mean values of all other characteristics. Because only $8 \%$ of the sample intends to make unequal bequests, this two percentage point change is equal to a $25 \%$ change in the predicted outcome. , In contrast, the "receives care" variable does not have a significant effect. ${ }^{14}$ Unlike the "receives care" variable, which refers to exchanges made in the past year, the poor health indicator may reflect mothers' long-term need for child assistance. If so, our findings suggest that mothers use intended, future transfers - which, presumably, they make known to their children - to elicit a long-term flow of services rather than current, short-term care. This type of behavior is predicted by Bernheim, Shleifer and Summers (1985), who emphasize the strategic use of bequests to influence child behavior over the remainder of the parent's life.

Table 2 also provides evidence that altruism may play a role in transfer decisions, in that larger within-family variation in children's income is associated with a higher probability of unequal intended bequests. Consider a two-child family in which one child's income is $\$ 25,000$ and the other's income is $\$ 50,000$. The coefficient of variation for this family is 47 (i.e., the standard deviation is $47 \%$ of the mean). If this hypothetical mother is "average" in all other respects, our estimates predict that her probability of intending unequal bequests is 4.7 percentage points higher than it would be if her children had the same income - an increase of nearly $60 \%$. This finding is consistent with altruistic behavior if we assume that she intends to give more to the low-income child. Of course, the result is also consistent with the exchange model if the mother intends to give more to the low-income child (for whom the price of time is also low) as payment for time-intensive services.

We find that mothers with only biological children (the omitted category) are significantly less likely to plan unequal bequests than are those with either adopted children or stepchildren. Having at least one stepchild increases the probability of intended unequal treatment by 4.1 percentage points, or over $50 \%$. The presence of an adopted child is associated with a similar, 3.8 percentage point increase. (The

\footnotetext{
${ }^{14}$ Care received includes help with personal care, household chores, and errands. If we limit the measure to personal care, the results remain virtually unchanged.
} 
difference between these two estimates is statistically insignificant.) Clearly, mothers with nonbiological children exhibit strikingly different behavior than do mothers with only biological children.

The final covariate for which we estimate a statistically significant coefficient is the dummy variable indicating that some of the mother's children have children of their own. The omitted group consists of mothers with no grandchildren and those for whom all children have children of their own. The positive estimate shown in table 2 reveals that mothers with children who are "mixed" in this regard are more likely to intend unequal bequests. We do not know that they will bequeath more to those children with children of their own, but such intentions would be consistent with altruistic behavior (insofar as families with children have the greatest financial need), exchange motives (if grandchildren supply affection and other "services") or evolutionary motives (given that biological grandchildren will carry on the family genes).

The logit estimates in table 2 do not constitute a formal test of any theory, but they provide descriptive evidence that all three competing models - altruism, exchange, and evolution — may play a role in intra-family transfer decisions. We cannot conclude with certainty that mothers in poor health are driven by exchange motives to divide their estates unequally among their children, nor do we know whether women whose children's incomes vary considerably are behaving altruistically or that mothers with nonbiological children are driven by evolutionary motives. In fact, as we have noted, each pattern is consistent with more than one model. To address this issue directly, we examine the reasons given by these mothers for intending unequal bequests to learn more about their motives.

\subsection{Self-reported reasons for intended unequal bequests}

As explained at the outset of section 4, mothers who report that they intend to divide their estates unequally are asked to explain why. The interviewer records their actual responses, so we have the mothers' own words rather than their selections from a list of possible responses. The explanations should thus be free from suggestion bias.

Table 3 gives examples of the verbatim responses and a summary of our efforts to classify them as reflecting exchange, altruism, or evolutionary motives. The vast majority of responses fit neatly into one of these categories. Among the 128 mothers providing a response, 22 refer to their children's financial needs in explaining why some will receive a larger bequest than others (e.g., "the oldest son has more assets than the youngest son."). These mothers' motives clearly conform to the altruism model. We include an additional 11 mothers who mention a child's disability (e.g., "my daughter can't have over $\$ 2000$ or she will lose her state benefits") in this category as well. We classify 33 responses under 
"exchange" because the mother refers to care-giving or attention provided by the child (e.g. "she takes care of me") or indicates that a child has displeased the parents (e.g. "because we are estranged from our daughter.") Another 13 responses directly refer to the child(ren)'s status as biological, adopted, or step. We classify these responses as "evolutionary," although they can also reflect altruism (because the mother might expect the child's other (birth) parent to provide for him/her) or exchange (if, for example, the mother interacts less extensively with her stepchildren than with her biological children).

Finally, we determine that another 25 mothers may not belong in the "unequal" sample at all. Despite initially reporting that their wills do not call for equal division of their estates, eight mothers provide an explanation indicating that, in fact, an equal division is intended. Typically the confusion arises when the children are beneficiaries only if the husband predeceases his wife (e.g. "My husband first and then my children.”). Another 13 mothers explain that other people (including grandchildren) are beneficiaries as well as their children; these women apparently intend to treat their children equally while giving them less than $100 \%$ of their estates (e.g. "It will be divided equally between XXX and my children."). Four mothers indicate that they intend to leave more for a minor child (e.g., to allow him/her to finish school), but they are likely to change their wills as their children age. Below, we assess the sensitivity of our logit estimates to alternative definitions of "unequal" based on these verbatim responses.

We leave the remaining 24 cases unclassified. One of these remaining respondents provides a long, detailed explanation that we cannot interpret, but the remaining 23 cases fall under the heading of "non-answers." A few women decline to provide a reason (one respondent tells the interview "that's a terrible question"), while others describe their intended distribution without explanation (e.g., "just one son gets it all.")

Our classification scheme requires some assumptions on our part, but we check responses against other data (e.g., the number, sex composition, and biological status of the children) to ensure that we are not misinterpreting respondents' remarks. Despite an inevitable level of ambiguity, we believe the verbatim responses are noteworthy for several reasons. First, 79 out of 128 mothers (62\%) give explanations that clearly suggest they are driven by exchange, altruism, and/or evolutionary motives; no mother explicitly describes motives that are inconsistent with these competing theoretical models. Second, mothers appear to be equally likely to be driven by altruism and exchange motives. We place 33 responses into each category, but even if we eliminate or reclassify the most ambiguous cases (such as those where the mother intends to favor the child who will serve as executor of the will) the breakdown between altruism and exchange is roughly equal. Third, mothers with a disabled or institutionalized child 
form a large share of the cases classified as altruism. Just as the altruism model predicts, families whose children differ dramatically in their innate abilities or outcomes have a strong incentive to differentiate among their children in transferring resources. ${ }^{15}$

Our next step is to reanalyze the probability of intended unequal bequests, using the verbatim responses to construct alternative definitions of unequal giving. The dependent variable used for the table 2 logit is based on answers to the question, "Will your estate be divided equally among your children?" Among the 128 women who answer "no," our interpretation of their reasons suggests that as many as 25 actually intend to make equal bequests (table 3). Our first alternative definition of unequal shifts all 25 from the unequal category to the equal category. Definition 2 shifts only 14 of those 25 cases to the equal category; mothers who intend to include grandchildren or favor minor children in their wills continue to be classified as "unequal."

We reestimate the logistic regression reported in table 2 for the two alternative definitions of inequality. The results are reported in table 4. In general, the coefficient estimates differ only slightly from table 2 and the main points continue to hold: using definitions 1 and 2, measures of the mother's financial status continue to have virtually no effect on the probability of intending unequal bequests, while stepchildren, adopted children, "some children having children" and variation in children's income are associated with higher probabilities of intended unequal bequests. The estimated coefficient for "poor/fair health" was significantly different from zero in table 2, but with both new definitions the point estimate decreases slightly while the standard error decreases. At the same time, the estimated coefficient for the "age 75+" dummy variable is estimated more precisely when we use definition 1 than in the other two specifications. Mothers' health status and age are highly correlated, of course, so it is unsurprising that slight changes in the sample affect the relative precision with which we identify their effects. ${ }^{16}$ In short, we find no dramatic changes in the correlates of intended unequal bequests when we use mothers' self-reported reasons to determine whether they really intend to treat their children unequally.

\footnotetext{
${ }^{15}$ The example in table 3 reflects classic altruistic behavior: the mother is saying that once a $\$ 2000$ cap is reached, the marginal utility of a dollar given to her disabled child is zero because it "crowds out" public benefits. At the same time, this behavior contradicts the key, testable prediction of the altruistic model, which is that children with the lowest income (including, presumably, most disabled children) receive the largest transfer. This example, and others like it, highlight the potential gains from looking beyond observed behavior.

16 The estimated coefficients for the "divorced" and "highest grade completed=16+" dummies also become statistically significant (at a 10\% level) when we use definition 1. Divorced (as well as widowed) mothers may be more likely than married women to need help from their children. More highly schooled mothers may understand the intricacies of using trusts to make unequal transfers better than do their less schooled counterparts. Because trusts avoid probate and, therefore, public disclosure of the details, parents may be more likely to make unequal bequests in this fashion.
} 
We have shown how characteristics of mothers and their children relate to the probability of intending unequal bequests, and we have examined mothers' self-reported reasons for their intentions. We now ask how these characteristics and reported reasons relate to each other. If "poor health" and "receives help from children" are proxies for exchange motives, we expect the reasons reported by women with these characteristics to fall into the exchange category more often than not. Similarly, women whose children's incomes vary considerably should report altruism-related reasons and women with nonbiological children should be the only ones whose reasons suggest they are favoring biological children.

In table 5, we show how the reported frequency of alternative explanations - altruism, exchange, evolutionary, or unclassified - varies by selected observed characteristics. ${ }^{17}$ The table reveals that among older mothers (age 75+) who intend to divide their estate unequally, 23\% give a reason that is consistent with altruism, $38 \%$ cite exchange, $15 \%$ refer to the biological status of their children, and $23 \%$ give a reason that we cannot classify. In comparison, a larger percentage (33\%) of their younger counterparts give a reason related to altruism while fewer of them (31\%) give an exchange motive. Similarly, mothers in "fair or poor" health are much less likely to provide an altruism-related reason than to provide an exchange-related reason ( $21 \%$ vs. $45 \%)$, while the opposite is true for mothers in better health. The same pattern is seen when we compare mothers who receive care from their children to mothers who do not. Because we are working with such small samples, chi-squared test statistics reveal that the difference in each pair of distributions is statistically significant at a $10 \%$ level only for the breakdown by "receives care" (a result that is due to a large difference in the fraction reporting an evolutionary explanation). Nonetheless, the data suggest that mothers whose characteristics suggest they might need care from their children are the most likely to cite exchange-related motives for intending unequal bequests.

The most striking contrasts in table 5 are related to the biological status of the children. Among mothers with only biological children, $44 \%$ report an altruistic reason, 34\% report a reason related to exchange and, of course, none indicate that they intend to favor their biological children with their bequests. In contrast, only $9 \%$ of mothers with step or adopted children report an altruistic reason, while $29 \%$ report an exchange motive and $37 \%$ report an evolutionary motive. A chi-squared test reveals the difference between these two distributions to be highly significant. We find similarly, statistically significant differences between small and large families. Women with relatively few children are far more likely than their counterparts to report a reason related to altruism (36\% vs. $18 \%)$ and far less likely

\footnotetext{
${ }^{17}$ We use the sample of 103 women who intend unequal bequests according to definition 1, but our results are the same if we use all 128 "unequal" mothers in the table 2 sample.
} 
to report an evolutionary reason ( $9 \%$ vs. 27\%). Mothers with many children are more likely to have at least one nonbiological child, at least one child in difficult financial straits (altruism), and at least one child with whom she has a distant relationship (exchange), so on a priori grounds it would be difficult to predict this particular pattern.

The one anomaly in table 5 concerns our measure of children's financial need. When we compare mothers for whom the coefficient of variation in children's predicted income is above and below the (bequest sample) median, we find the two groups are equally likely to provide an altruistic motive. ${ }^{18}$ The logit estimates in tables 2 and 4 reveal this variable to be positively correlated with the probability that the mother intends unequal bequests. We now find it is uncorrelated with the probability that the mother explains her intentions in a manner that we classify as altruism. However, as we noted earlier, the exchange model also predicts a potential relationship between transfers and within-family variation in child income, although it does not predict whether high or low-income children receive greater transfers. Table 5 shows that mothers with high-variation children have a slightly greater tendency than others to report an exchange motive. It is possible that the expected relationship is obscured by the interplay of both altruistic and exchange-related motives.

The evidence presented here tells a consistent story: relatively few mothers intend to differentiate among their children in making bequests, but those who do appear to be driven by both altruism and exchange motives. The biological status of the children is also key - but, as we have discussed, only $16 \%$ of mothers have nonbiological children, and among those mothers the desire to favor biological children may reflect altruism, exchange, or evolutionary motives.

\section{Inter vivos transfers}

While relatively few parents divide their estates unequally among their children, researchers consistently find that the vast majority of parents who make inter vivos transfers give unequal amounts. Respondents in the NLS report information on transfers made to their children in the last year, so we can follow up our analysis of bequests with a similar investigation of inter vivos transfers. In doing so, we assess whether patterns in the NLS data are similar to those found in other data sets, and we address several more substantive questions. First, do the same observable proxies for altruistic, exchange, and evolutionary motives (poor health, having nonbiological children, etc.) that predict the probability of unequal bequests also predict the probability of unequal transfers? Second, do mothers who intend unequal bequests also

\footnotetext{
${ }^{18}$ Even when we use a more extreme breakdown — coefficient of variation of children's income in the top quartile versus the bottom three quartiles - we find little difference in the percentage of mothers expressing an altruistic motive.
} 
make unequal inter vivos transfers? Third, do mothers who self-report altruistic, exchange, and evolutionary motives for their bequest decisions differ in their likelihood of making unequal inter vivos transfers? From a theoretical perspective, it is not clear how patterns of inter vivos transfers and intended bequests should be related. On one hand, we expect mothers to exhibit consistent behavior over time: whether they are motivated by altruism, exchange, or evolution, their propensity to treat their children differently should be independent of when the transfer is made. On the other hand, a mother may achieve her desired allocation of resources by making unequal transfers during her lifetime and revert to equal giving for bequests.

To address these issues, we use the "transfers sample" described in section 3. This sample contains the subset of mothers in the bequest sample who answer a series of questions about transfers made to their children in the last 12 months and who report having made transfers. For up to five individual children, mothers report the dollar amounts they (and their husbands) lent to the child (and his/her spouse), gave as cash, gave as gifts, and gave as "other financial assistance"; there is no minimum amount for a transfer to be counted. We add the transfer amounts made in all categories to get the total transfer to each child. Among the 855 mothers in the transfer sample, the mean transfer amount per child is $\$ 1,980$ (with a standard error of 144 ) and the median is $\$ 500$.

Our first task is to determine how mothers allocate inter vivos transfers among their children. Table 6 reveals that $17.7 \%$ of the 855 mothers give exactly the same dollar amounts to each (in-sample) child. Another $7.8 \%$ differentiate among their children, but give amounts that are all within $20 \%$ of the within-family mean. The remaining $75 \%$ of mothers have even more variation in their inter vivos transfers. Table 6 also reveals that $70 \%$ of mothers make a positive transfer to each of their children, so it is not the case that unequal transfers arise only when a mother gives gifts or money to one child but not another. In the remainder of our analysis, we use a strict definition of unequal transfers and count as unequal the $82.3 \%$ of mothers who do not give exactly equal transfers to each child. Our results do not change significantly if we move the $7.8 \%$ falling within the $20 \%$ band from the unequal category to the equal category.

In table 7 we present logit estimates of the probability that a mother makes unequal inter vivos transfers. In specification 1, the explanatory variables are identical to the ones used to examine unequal intended bequests (tables 2 and 4). When we use this specification the estimated coefficients for several variables are qualitatively similar to what we found for the probability of unequal bequests: Mothers' income, assets, home ownership, and schooling continue to have insignificant effects. The estimated coefficients for "poor health" and "some children have children" continue to be positive, although in 
contrast to the table 2 estimates they are no longer statistically significant. The coefficient of variation of children's income is positively and significantly associated with the probability of intending unequal transfers, just as it is with the probability of unequal bequests.

Table 7 also reveals a number of estimates for specification 1 that differ from what we saw for bequests. First, in table 7 we see that younger mothers (who have younger children, on average) are considerably more likely than older mothers to make unequal transfers to their children; when it comes to bequests, older mothers are the most likely to favor unequal allocations. Second, while the presence of stepchildren and adopted children are both strongly, positively associated with the probability of unequal bequests, table 7 reveals both to be less important determinants of transfer allocations. The probability that mothers with stepchildren make unequal transfers is 13 percentage points higher than the probability for mothers with no nonbiological children, but this amounts to only a $16 \%$ change in the unconditional probability of $82.3 \%$. The presence of an adopted child has virtually no effect on the probability of unequal transfers. ${ }^{19}$ Third, mothers with coresident children are far more likely than others to make unequal transfers; this difference does not appear when we examine the probability of unequal bequests. Although the logit model is silent on which children are receiving the larger transfers, a closer look at the data reveals that the average transfer to coresident children is roughly $30 \%$ larger than the average transfer to non-coresident children. This evidence is consistent with coresident children being relatively needy and mothers altruistically providing them with cash transfers in addition to housing. (If this neediness is transitory it would not necessarily affect the distribution of bequests, which may be many years away.) It is also consistent with exchange if coresident children tend to help their mothers morehowever, the estimated coefficient for the "receives help from children" indicator is statistically insignificant in specification 1 , and remains virtually unchanged when we drop the "coresident" variable from the model.

In table 8 , we use the transfers sample to assess the unconditional relationship between unequal giving with respect to bequests and inter vivos transfers. Table 8 shows that the majority of mothers (77\% of the sample) make unequal inter vivos transfers and intend to make equal bequests. Other data sources have revealed these two patterns of giving to be the norm, so we would be very surprised if they were not revealed in our data. Only 16 mothers ( $2 \%$ of the sample) choose the reverse combination of unequal bequests and equal inter vivos transfers. What is noteworthy about the numbers in table 8 is that although the sample sizes are small, it appear that mothers who intend to make unequal bequests make

\footnotetext{
${ }^{19}$ As we noted earlier, stepchildren are more likely than adopted children to have other parents who can provide them with resources. Therefore, this differential behavior on the part of mothers could reflect altruistic motives rather than an evolutionary desire to advance their genes.
} 
equal transfers at a higher rate than other mothers. The 61 mothers in the unequal bequests category are, of course, far more likely than other mothers to be "consistent" in their transfer behavior: $74 \%$ of them not only intend to make unequal bequests, but actually make unequal transfers. However, the remaining $26 \%$ make equal transfers, which is a higher rate than the $17 \%$ seen for the rest of the sample.

To learn more about the temporal consistency of mothers' transfer behavior, we examine the conditional relationship between intended unequal bequests and actual unequal transfers by reestimating the logistic regression of table 7 after including a dummy variable indicating whether the mother intends to divide her estate unequally. The results appear as specification 2 in table 7. This addition has little effect on the estimated coefficients for the other covariates, but it is clear that, ceteris paribus, mothers who intend to make unequal bequests are less likely than other mothers to make unequal inter vivos transfers. The estimated coefficient for "unequal bequests" is -0.938 and statistically significant; mothers in this category are 8.5 percentage points less likely to distribute cash, gifts, and loans unequally among their children. This finding is consistent with the unconditional pattern seen in table 8.

In summary, we find that observed proxies for altruistic, exchange and evolutionary giving ("has stepchildren," the coefficient of variation of children's income, etc.) generally affect the probability of unequal inter vivos transfers the same way they affect the probability of intended unequal bequests. However, mothers who intend to make unequal bequests do not always make unequal transfers. Whether we condition on observed characteristics or not, we find that these mothers are somewhat less likely than the remaining sample members to make unequal transfers.

\section{Concluding remarks}

Researchers have been frustrated in their efforts to understand the motives behind intra-family transfers. Available data have been extensively analyzed, but have failed to provide conclusive support for models of altruism, exchange, or evolution. Our contribution is to use new data for a sample of 45-80 year-old mothers who participate in the National Longitudinal Surveys of Young Women and Mature Women. These data include a feature not available in other surveys: verbatim explanations for why mothers intend to divide their estates unequally among their children.

Our analysis of the verbatim responses suggests that a variety of motives come into play when mothers establish their wills. Among mothers who intend to divide their estates unequally among their children, 25\% provide explanations that are consistent with altruism and another $25 \%$ give reasons suggesting they intend to exchange bequests for child-provided services. Fewer than one in five mothers has nonbiological children, yet $10 \%$ of mothers refer to stepchildren or adopted children in their response. 
(Among mothers with a nonbiological child, roughly one in three falls into this category.) We term these responses "evolutionary," although mothers who favor their biological children may be motivated by altruism or exchange rather than genetic links. Another $20 \%$ of mothers give reasons suggesting that, in fact, they intend an equal distribution of their estate, and the remaining $20 \%$ of mothers remain unclassified because their explanations do not reveal their motives. Based on mothers' own explanations for their decisions to treat their children unequally, it appears that altruism and exchange are equally prominent motives.

When we bring characteristics of mothers and their children into the analysis, the evidence continues to point to a variety of motives for mother-to-child transfers. Such factors as poor maternal health, the presence of nonbiological children, and increased within-family variation in children's predicted income are associated with a higher probability of intended unequal bequests. These patterns are consistent with altruistic, exchange, and evolutionary motives for unequal giving - a conclusion that is strengthened by our finding that, for example, mothers in poor health are more likely than others to give an exchange-related explanation for their intended unequal bequests.

By comparing mothers' actual divisions of inter vivos transfers with their intended bequests, we find that relatively few mothers appear to adhere to the same patterns over time. In our data, more than three out of four mothers distribute inter vivos transfers unequally among their children while intending to make equal bequests. We also find that the relatively small subset of mothers who intend to make unequal bequests are more likely than other mothers to make equal inter vivos transfers. Both findings confirm the widely-accepted view that parents behave differently when making inter vivos transfers and bequests.

The patterns seen in our data indicate that the operative motive for parent-to-child transfer decisions likely varies across parents and over time for a given parent. The finding that each competing model-altruism, exchange, and evolution-plays a potentially important empirical role has practical as well as theoretical interest. After all, the extent to which income inequality changes across generations is very much dependent on whether parents favor their low-income children when transferring resources. Similarly, the ability of intra-family transfers to offset or crowd-out government spending depends on whether families are altruistic. To address these long-standing policy issues, we do not need a single, "correct" theoretrical model. Instead, we need additional evidence on when and for whom the alternative motives drive intra-family transfer decisions. 


\section{References}

Altonji, Joseph, Fumio Hayashi and Laurence Kotlikoff, 1992. "Is the Extended Family Altruistically Linked? Direct Evidence Using Micro Data," American Economic Review 82 (5): 1177-1198.

Altonji, Joseph, Fumio Hayashi and Laurence Kotlikoff, 1997. "Parental Altruism and Inter Vivos Transfers: Theory and Evidence," Journal of Political Economy 105 (6): 1121-1166.

Andreoni, James, 1989. "Giving with Impure Altruism: Applications to Charity and Ricardian Equivalence," Journal of Public Economics 97 (6): 1447-1458.

Barro, Robert, 1974. “Are Government Bonds New Wealth?” Journal of Political Economy 82 (6): 10951117.

Bassett, William F. and Robin L. Lumsdaine, 2003. "Outlook, Outcomes, and Optimism," mimeo, Federal Reserve Board of Governors.

Becker, Gary S., 1974. “A Theory of Social Interactions,” Journal of Political Economy 82 (6): 10631093.

Becker, Gary S. and Nigel Tomes, 1979. "An Equilibrium Theory of the Distribution of Income and Intergenerational Mobility," Journal of Political Economy 87 (6): 1153-1189.

Bernheim, B. Douglas, and Sergei Severinov, 2000. "Bequests as Signals: An Explanation for the Equal Division Puzzle," NBER working paper 7791.

Bernheim, B. Douglas, Andrei Shleifer, and Lawrence Summers, 1985. "The Strategic Bequest Motive," Journal of Political Economy 93 (6): 1045-1076.

Coward, Raymond and Jeffery Dwyer, 1990. "The Association of Gender, Sibling Network Composition, and Patterns of Parent Care by Adult Children," Research on Aging 12 (2): 158-181.

Cox, Donald, 1987. "Motives for Private Income Transfers," Journal of Political Economy 95 (3): 508546.

Cox, Donald, in press. "Fathers, Mothers, Sons, and Daughters: How Do People Decide to Allocate Transfers Among Family Members?" In Alicia H. Munnell and Annika Sundén (eds.), Death and Dollars: the Role of Gifts and Bequests in America, Washington, D.C.: Brookings Institution Press.

Cox, Donald and Mark R. Rank, 1992. "Inter-Vivos Transfers and Intergenerational Exchange," Review of Economics and Statistic 74 (2): 305-314.

Cox, Donald and Oded Stark, 1999. "On the Demand for Grandchildren: Tied Transfers, Liquidity Constraints, and the Demonstration Effect," mimeo, Boston College.

Dominitz, Jeffrey, 1998. "Earnings Expectations, Revisions and Realizations," The Review of Economics and Statistics, 80(3): 374-388.

Dunn, Thomas A. and John W. Phillips, 1997. "The Timing and Division of Parental Transfers to Children." Economics Letters 54: 135-137.

Hochguertel, Stefan and Henry Ohlsson, 2000. "Compensatory inter vivos Gifts," mimeo, European University Institute.

Hurd, Michael D. and Kathleen McGarry, 2002. "The Predictive Validity of Subjective Probabilities of Survival." The Economic Journal, 112(482): 966-985.

Laitner, John and F. Thomas Juster, 1996. "New Evidence on Altruism: A Study of TIAA-CREF Retirees," American Economic Review 86 (4): 893-908. 
Laitner, John and Henry Ohlsson, 2001. "Bequest Motives: A Comparison of Sweden and the United States." Journal of Public Economics 79 (1): 205-236.

Manski, Charles, 1990. "The Use of Intentions Data to Predict Behavior: A Best Case Analysis." Journal of the American Statistical Association, 85 : 934-940.

McGarry, Kathleen, 1999. "Inter vivos Transfers and Intended Bequests, ” Journal of Public Economics 73 (3): 321-351.

McGarry, Kathleen, 2000. "Testing Parental Altruism: Implications of a Dynamic Model." NBER working paper 7593.

McGarry, Kathleen and Robert Schoeni, 1995. "Transfer Behavior: Measurement and the Redistribution of Resources Within the Family," Journal of Human Resources 30 (supplement): s184-s226.

McGarry, Kathleen and Robert Schoeni, 1997. "Transfer Behavior within the Family: Results from the Asset and Health Dynamics Survey," The Journals of Gerontology 52B (special issue): 82-92.

Menchik, Paul, 1980. "Primogeniture, Equal Sharing and the U.S. Distribution of Wealth," Quarterly Journal of Economics 94 (2): 299-316.

Menchik, Paul, 1988. "Unequal Estate Division: Is it Altruism, Reverse Bequests, or Simply Noise?" In Denis Kessler and André Masson (eds.), Modelling the Accumulation and Distribution of Wealth, Oxford: Clarendon Press.

Perozek, Maria, 1998. "A Reexaminiation of the Strategic Bequest Motive," Journal of Political Economy 106 (2): 423-445.

Schoeni, Robert, 2001. "Support Networks within the Family as a Public Good Problem," mimeo, University of Michigan.

Stoller, Eleanor Palo, Lorna Earl Foster, and Tamara Sutin Duniho, 1992. "Systems of Parent Care within Sibling Networks," Research on Aging 14 (1): 28-49.

Tomes, Nigel, 1981. "The Family, Inheritance and the Intergenerational Transmission of Inequality," Journal of Political Economy 89 (5): 928-958.

Tomes, Nigel, 1988. "Inheritance and Inequality with the Family: Equal Division Among Unequals, or Do the Poor Get More?" In Denis Kessler and André Masson (eds.), Modelling the Accumulation and Distribution of Wealth, Oxford: Clarendon Press.

Wilhelm, Mark, 1996. "Bequest Behavior and the Effect of Heirs' Earnings: Testing the Altruistic Model of Bequests," American Economic Review 86 (4): 874-892. 
Table 1: Summary Statistics for Selected Mother-Specific Variables

\begin{tabular}{|c|c|c|c|c|c|c|}
\hline \multirow[b]{2}{*}{ Variables } & \multicolumn{2}{|c|}{ Full sample } & \multicolumn{2}{|c|}{ Bequest sample } & \multicolumn{2}{|c|}{ Transfers sample } \\
\hline & Mean & S.E. & Mean & S.E. & Mean & S.E. \\
\hline \multicolumn{7}{|l|}{ Financial status } \\
\hline $\begin{array}{l}\text { Family income }(\$ 1,000 \mathrm{~s}) \\
\text { (median) }\end{array}$ & $\begin{array}{c}35.82 \\
(20.33)\end{array}$ & .69 & $\begin{array}{c}41.30 \\
(25.38)\end{array}$ & 1.14 & $\begin{array}{c}49.04 \\
(31.11)\end{array}$ & 1.72 \\
\hline $\begin{array}{l}\text { Family assets }(\$ 10,000 \mathrm{~s}) \\
(\text { median })\end{array}$ & $\begin{array}{l}22.55 \\
(9.76)\end{array}$ & .91 & $\begin{array}{c}33.21 \\
(18.75)\end{array}$ & 1.36 & $\begin{array}{c}39.20 \\
(22.85)\end{array}$ & 2.10 \\
\hline 1 if own home & .81 & & .92 & & .93 & \\
\hline Highest grade completed & 12.32 & .05 & 13.05 & .06 & 13.37 & .08 \\
\hline \multicolumn{7}{|l|}{ Demographics } \\
\hline Age & 60.34 & .17 & 62.04 & .24 & 61.25 & .33 \\
\hline 1 if white & .76 & & .89 & & .91 & \\
\hline 1 if married & .62 & & .70 & & .70 & \\
\hline 1 if widowed & .19 & & .18 & & .17 & \\
\hline 1 if divorced & 18 & & .12 & & .13 & \\
\hline 1 if never married & .02 & & .00 & & .00 & \\
\hline \multicolumn{7}{|l|}{ Health status } \\
\hline 1 if in poor/fair health & .27 & & .20 & & .19 & \\
\hline 1 if receives help from child(ren) & .37 & & .37 & & .44 & \\
\hline \multicolumn{7}{|l|}{ Child variables } \\
\hline Number of children & 3.68 & .03 & 3.39 & .04 & 3.12 & .05 \\
\hline 1 if has only boys & .13 & & .14 & & .15 & \\
\hline 1 if has only girls & .13 & & .15 & & .16 & \\
\hline 1 if has both boys and girls & .74 & & .71 & & .69 & \\
\hline Number of biological children & 3.30 & .03 & 3.04 & .04 & 2.81 & .04 \\
\hline 1 if has only biological child(ren) & .83 & & .84 & & .84 & \\
\hline 1 if has step child(ren) & .14 & & .13 & & .11 & \\
\hline 1 if has adopted child(ren) & .03 & & .04 & & .05 & \\
\hline Number of coresident children & .39 & .01 & .31 & .01 & .38 & .02 \\
\hline 1 if has coresident child(ren) & .30 & & .24 & & .28 & \\
\hline Number of grandchildren & 5.09 & .09 & 4.46 & .11 & 3.77 & .14 \\
\hline 1 if has grandchild(ren) & .84 & & .81 & & .78 & \\
\hline 1 if some children have child(ren) & .55 & & .51 & & .50 & \\
\hline 1 if all children have child(ren) & .30 & & .30 & & .28 & \\
\hline $\begin{array}{l}\text { Coeff. of within-family variation for } \\
\text { children's predicted income }\end{array}$ & 33.43 & .37 & 41.30 & 1.14 & 31.97 & .70 \\
\hline Number of mothers & 3,4 & & 1,6 & & & \\
\hline
\end{tabular}


Table 2: Logit Estimates of the Probability that a Mother Intends to Divide her Estate Unequally Among her Children

\begin{tabular}{|c|c|c|c|}
\hline Variable & Coeff. & S.E. & $\begin{array}{l}\text { Marg. } \\
\text { effect }\end{array}$ \\
\hline Intercept & -3.733 & .539 & \\
\hline Family income ( $\$ 1000 \mathrm{~s})$ & .004 & .002 & .000 \\
\hline Family assets $(\$ 10000 \mathrm{~s})$ & -.000 & .002 & -.000 \\
\hline 1 if owns home & -.051 & .338 & -.003 \\
\hline 1 if highest grade completed $<12$ & .249 & .286 & .014 \\
\hline highest grade $=13-15$ & .274 & .243 & .015 \\
\hline highest grade $=16+$ & -.210 & .286 & -.014 \\
\hline 1 if age $=45-54$ & .116 & .293 & .007 \\
\hline age $=65-74$ & .150 & .281 & .009 \\
\hline age $=75+$ & .384 & .398 & .020 \\
\hline 1 if nonwhite & .193 & .289 & .011 \\
\hline 1 if widowed & .229 & .267 & .013 \\
\hline divorced & .431 & .312 & .022 \\
\hline 1 if in poor/fair health & .379 & .230 & .020 \\
\hline 1 if receives help from child(ren) & -.190 & .239 & -.013 \\
\hline Number of children & -.078 & .066 & -.005 \\
\hline 1 if has both boys and girls & .117 & .234 & .007 \\
\hline 1 if has stepchild(ren) & 1.005 & .254 & .041 \\
\hline 1 if has adopted child(ren) & .910 & .351 & .038 \\
\hline 1 if has coresident child(ren) & .079 & .264 & .005 \\
\hline 1 if some children have child(ren) & .334 & .200 & .018 \\
\hline $\begin{array}{l}\text { Coefficient of variation for children's } \\
\text { predicted income }\end{array}$ & .017 & .005 & .001 \\
\hline Log likelihood & \multicolumn{3}{|c|}{-417.482} \\
\hline Number of observations & \multicolumn{3}{|c|}{1,618} \\
\hline Number (percent) with unequal $=1$ & \multicolumn{3}{|c|}{$128(7.9 \%)$} \\
\hline
\end{tabular}

Note: Estimated coefficients in bold face are statistically different than zero at a $10 \%$ significance level. Marginal effects are computed at the sample mean. 
Table 3: Examples of Reasons for Intended Unequal Bequests

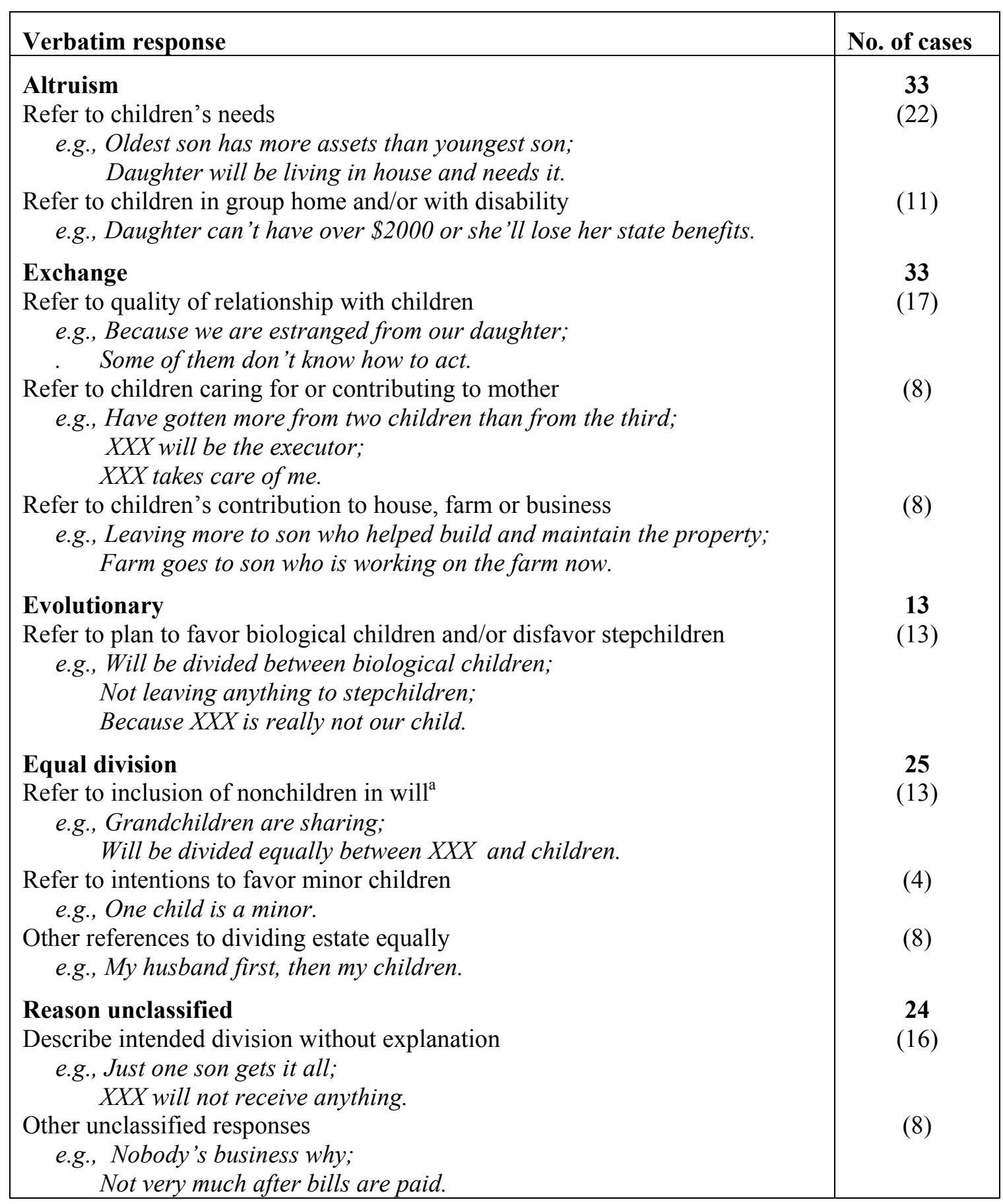

Note: These are verbatim responses (paraphrased for brevity) to the question: Why will your estate not be divided equally among your children? It is asked of 128 respondents with more than one child who report that they (a) have a will, (b) intend to leave something to their children, and (c) intend not to divide their estate equally among their children.

${ }^{a} 7$ of the 13 cases refer exclusively to grandchildren. Grandchildren are also referred to in 3 responses classified under exchange and one response classified as altruism. 
Table 4: Logit Estimates of the Probability that a Mother Intends to Divide her Estate Unequally Among her Children

(using alternative definitions of "unequal" based on verbatim responses)

\begin{tabular}{|c|c|c|c|c|c|c|}
\hline \multirow[b]{2}{*}{ Variable } & \multicolumn{3}{|c|}{ Definition $1^{\mathrm{a}}$} & \multicolumn{3}{|c|}{ Definition $2^{\mathrm{a}}$} \\
\hline & Coeff. & S.E. & $\begin{array}{l}\text { Marg. } \\
\text { effect }\end{array}$ & Coeff. & S.E & $\begin{array}{l}\text { Marg. } \\
\text { effect }\end{array}$ \\
\hline Intercept & -4.271 & .599 & & -3.891 & .570 & \\
\hline Family income $(\$ 1000 \mathrm{~s})$ & .003 & .003 & .000 & .002 & .003 & .000 \\
\hline Family assets $(\$ 10,000 \mathrm{~s})$ & .001 & .002 & .000 & .001 & .002 & .000 \\
\hline 1 if owns home & -.149 & .354 & -.008 & -.074 & .352 & -.004 \\
\hline 1 if highest grade completed $<12$ & .234 & .301 & .010 & .322 & .289 & .015 \\
\hline highest grade $=13-15$ & .149 & .267 & .007 & .259 & .253 & .012 \\
\hline highest grade $=16+$ & -.625 & .351 & -.039 & -.515 & .328 & -.035 \\
\hline 1 if age $=45-54$ & .248 & .347 & .010 & .224 & .320 & .011 \\
\hline age $=65-74$ & .448 & .324 & .017 & .270 & .302 & .013 \\
\hline age $=75+$ & .786 & .429 & .026 & .559 & .413 & .023 \\
\hline 1 if nonwhite & .088 & .322 & .004 & .156 & .304 & .008 \\
\hline 1 if widowed & .349 & .281 & .014 & .212 & .275 & .010 \\
\hline divorced & .470 & .352 & .018 & .326 & .338 & .015 \\
\hline 1 if in poor/fair health & .318 & .252 & .013 & .334 & .241 & .016 \\
\hline 1 if receives help from child(ren) & -.213 & .266 & -.011 & -.138 & .251 & -.008 \\
\hline Number of children & -.061 & .069 & -.003 & -.081 & .068 & -.004 \\
\hline 1 if has both boys and girls & .394 & .275 & .016 & .253 & .253 & .012 \\
\hline 1 if has stepchild(ren) & .941 & .278 & .030 & .958 & .267 & .034 \\
\hline 1 if has adopted child(ren) & .977 & .380 & .030 & .948 & .365 & .034 \\
\hline 1 if has coresident child(ren) & .167 & .290 & .007 & .025 & .280 & .001 \\
\hline 1 if some children have child(ren) & .411 & .233 & .016 & .437 & .221 & .020 \\
\hline $\begin{array}{l}\text { Coefficient of variation for } \\
\text { children's predicted income }\end{array}$ & .015 & .005 & .001 & .015 & .005 & .001 \\
\hline $\begin{array}{l}\text { Log likelihood } \\
\text { Number of observations } \\
\text { Number (percent) with unequal=1 }\end{array}$ & & $\begin{array}{r}-354.1 \\
1,61 \\
103(6 .\end{array}$ & & & $\begin{array}{r}-383.3 \\
1,61 \\
114(7 .\end{array}$ & \\
\hline
\end{tabular}

an definition 1, a mother is classified as intending unequal bequests if she (a) reports that she intends to divide her estate unequally among her children and (b) gives a reason that does not suggest that equal division is her true intent. In definition 2, we reclassify as "unequal" 11 mothers whose reason for intending unequal bequests is that they plan to give more to a minor child $(n=4)$ or include grandchildren in their will $(\mathrm{n}=7)$. See text for details.

Note: Estimated coefficients in bold face are statistically different than zero at a $10 \%$ significance level. Marginal effects are computed at the sample mean. 


\section{Table 5: Distribution of Reasons for Intended Unequal Bequests, by Selected Characteristics (sample is mothers who intend to divide their estates unequally)}

\begin{tabular}{|c|c|c|c|c|c|c|c|}
\hline & \multicolumn{4}{|c|}{ Reason for intended unequal bequest } & \multirow[b]{2}{*}{$\begin{array}{l}\chi^{2} \text { test } \\
\text { stat. }^{a}\end{array}$} & \multirow[b]{2}{*}{$\begin{array}{c}\mathrm{P}- \\
\text { value }\end{array}$} \\
\hline & & Altruism & Exchange & $\begin{array}{l}\text { Evolu- } \\
\text { tionary }\end{array}$ & $\begin{array}{l}\text { Not } \\
\text { classif. }\end{array}$ & & \\
\hline All mothers & 103 & .32 & .32 & .13 & .23 & & \\
\hline $\begin{array}{c}1 \text { if highest grade completed }=16+ \\
\text { highest grade completed }<16\end{array}$ & $\begin{array}{l}12 \\
91\end{array}$ & $\begin{array}{l}.25 \\
.33\end{array}$ & $\begin{array}{l}.50 \\
.30\end{array}$ & $\begin{array}{l}.17 \\
.12\end{array}$ & $\begin{array}{l}.08 \\
.25\end{array}$ & 3.06 & $.383^{b}$ \\
\hline $\begin{array}{c}1 \text { if age }=75+ \\
\text { age }<75\end{array}$ & $\begin{array}{l}13 \\
99\end{array}$ & $\begin{array}{l}.23 \\
.33\end{array}$ & $\begin{array}{l}.38 \\
.31\end{array}$ & $\begin{array}{l}.15 \\
.12\end{array}$ & $\begin{array}{l}.23 \\
.23\end{array}$ & 0.66 & $.884^{\mathrm{b}}$ \\
\hline $\begin{array}{l}1 \text { if married } \\
\text { widowed or divorced }\end{array}$ & $\begin{array}{l}64 \\
39\end{array}$ & $\begin{array}{l}.31 \\
.33\end{array}$ & $\begin{array}{l}.30 \\
.36\end{array}$ & $\begin{array}{l}.16 \\
.08\end{array}$ & $\begin{array}{l}.23 \\
.23\end{array}$ & 1.53 & .674 \\
\hline $\begin{array}{l}1 \text { if in poor/fair health } \\
\text { not in poor/fair health }\end{array}$ & $\begin{array}{l}29 \\
74\end{array}$ & $\begin{array}{l}.21 \\
.36\end{array}$ & $\begin{array}{l}.45 \\
.27\end{array}$ & $\begin{array}{l}.10 \\
.14\end{array}$ & $\begin{array}{l}.24 \\
.23\end{array}$ & 3.86 & .277 \\
\hline $\begin{array}{l}1 \text { if receives care from children } \\
\text { receives no care from children }\end{array}$ & $\begin{array}{l}37 \\
66\end{array}$ & $\begin{array}{l}.35 \\
.30\end{array}$ & $\begin{array}{l}.41 \\
.27\end{array}$ & $\begin{array}{l}.03 \\
.18\end{array}$ & $\begin{array}{l}.22 \\
.24\end{array}$ & 6.05 & .109 \\
\hline $\begin{array}{r}1 \text { if number of children } \leq 4 \\
\text { number of children }>4\end{array}$ & $\begin{array}{l}81 \\
22\end{array}$ & $\begin{array}{l}.36 \\
.18\end{array}$ & $\begin{array}{l}.33 \\
.27\end{array}$ & $\begin{array}{l}.09 \\
.27\end{array}$ & $\begin{array}{l}.22 \\
.27\end{array}$ & 6.82 & .078 \\
\hline $\begin{array}{l}1 \text { if all children are biological } \\
\text { have step/adopted children }\end{array}$ & $\begin{array}{l}68 \\
35\end{array}$ & $\begin{array}{l}.44 \\
.09\end{array}$ & $\begin{array}{l}.34 \\
.29\end{array}$ & $\begin{array}{r}0 \\
.37\end{array}$ & $\begin{array}{l}.22 \\
.26\end{array}$ & 34.70 & .001 \\
\hline $\begin{array}{l}1 \text { if some children have children } \\
\text { all/no children have children }\end{array}$ & $\begin{array}{l}67 \\
36\end{array}$ & $\begin{array}{l}.33 \\
.31\end{array}$ & $\begin{array}{l}.36 \\
.25\end{array}$ & $\begin{array}{l}.12 \\
.14\end{array}$ & $\begin{array}{l}.19 \\
.31\end{array}$ & 2.21 & .529 \\
\hline $\begin{array}{l}1 \text { if c.v. for kids' inc. } \leq \text { median } \\
\text { c.v. for kids' inc. }>\text { median }\end{array}$ & $\begin{array}{l}38 \\
65\end{array}$ & $\begin{array}{l}.34 \\
.31\end{array}$ & $\begin{array}{l}.29 \\
.34\end{array}$ & $\begin{array}{l}.05 \\
.17\end{array}$ & $\begin{array}{l}.32 \\
.18\end{array}$ & 4.62 & .202 \\
\hline
\end{tabular}

${ }^{a} \chi^{2}$ statistic for a test of the null hypothesis that the distribution of reported reasons is the same for each pair of independent subsamples.

${ }^{b}$ Expected frequencies for some cells are less than five. 
Table 6: Percent of Mothers Making No Inter Vivos Transfers, Equal Transfers, and Unequal Transfers

\begin{tabular}{|lr|}
\hline & Percent \\
\hline Equal transfers to all children & 17.7 \\
Unequal transfers, but within 20\% of family mean for all children & 7.8 \\
Other unequal transfers & 74.5 \\
& 100.0 \\
Percent making transfers to all children & 70.3 \\
\hline Number of mothers & 855 \\
\hline
\end{tabular}

Note: mothers are asked whether they (and their husbands) lent money, gave money, gave gifts, and provided other financial assistance to each child (and his/her spouse) in the last 12 months; those who answer "yes" for any category are asked the amount given. We add the transfer amounts made in all categories to get a transfer amount for each child. 
Table 7: Logit Estimates of the Probability that a Mother Made Unequal Inter Vivos Transfers to Each of Her Children in the Past Year

\begin{tabular}{|c|c|c|c|c|c|c|}
\hline \multirow[b]{2}{*}{ Variable } & \multicolumn{3}{|c|}{ Specification 1} & \multicolumn{3}{|c|}{ Specification 2} \\
\hline & Coeff. & S.E. & $\begin{array}{l}\text { Marg. } \\
\text { effect }\end{array}$ & Coeff. & S.E. & $\begin{array}{l}\text { Marg. } \\
\text { effect }\end{array}$ \\
\hline Intercept & 1.563 & .600 & & 1.526 & .605 & \\
\hline 1 if age $=45-54$ & .043 & .314 & .006 & .070 & .316 & .009 \\
\hline age $=65-74$ & -.684 & .282 & -.069 & -.667 & .282 & -.067 \\
\hline age $=75+$ & -.618 & .297 & -.065 & -.594 & .398 & -.061 \\
\hline 1 if nonwhite & .348 & .390 & .051 & .378 & .394 & .055 \\
\hline 1 if widowed & .169 & .274 & .023 & .198 & .276 & .027 \\
\hline Divorced & .088 & .326 & .012 & .104 & .328 & .014 \\
\hline 1 if highest grade completed $<12$ & -.276 & .318 & -.032 & -.273 & .320 & -.032 \\
\hline highest grade $=13-15$ & .102 & .252 & .014 & .117 & .254 & .015 \\
\hline highest grade $=16+$ & -.036 & .247 & -.005 & -.076 & .248 & -.009 \\
\hline Family income (\$1000s) & -.001 & .002 & -.000 & -.001 & .002 & -.000 \\
\hline Family assets $(\$ 10,000 \mathrm{~s})^{\mathrm{a}}$ & .000 & .002 & .000 & .000 & .002 & .000 \\
\hline 1 if owns home & -.353 & .423 & -.040 & -.412 & .427 & -.045 \\
\hline 1 if in poor/fair health & .193 & .266 & .027 & .218 & .268 & .030 \\
\hline 1 if receives help from child(ren) & .253 & .225 & .036 & .238 & .225 & .033 \\
\hline Number of children & -.130 & .079 & -.017 & -.108 & .081 & -.014 \\
\hline 1 if has only both boys and girls & .130 & .208 & .018 & .147 & .209 & .020 \\
\hline 1 if has stepchild(ren) & .800 & .396 & .134 & .986 & .411 & .171 \\
\hline 1 if has adopted child(ren) & -.093 & .448 & -.012 & -.020 & .451 & -.003 \\
\hline 1 if has coresident child(ren) & .829 & .286 & .140 & .837 & .286 & .140 \\
\hline 1 if some children have child(ren) & .208 & .200 & .029 & .221 & .202 & .030 \\
\hline $\begin{array}{l}\text { Coefficient of variation for } \\
\text { children's predicted income }\end{array}$ & .015 & .005 & .002 & .017 & .005 & .002 \\
\hline 1 if unequal bequests (def'n 1 ) & & & & -.938 & .345 & -.085 \\
\hline Log likelihood & & -369.25 & & & -363.0 & \\
\hline Number of observations & & 855 & & & 855 & \\
\hline Number (percent) with unequal $=1$ & & $04(82.3$ & & & $704(82$. & \\
\hline
\end{tabular}

Note: Estimated coefficients in bold face are statistically different than zero at a $10 \%$ significance level. Marginal effects are computed at the sample mean. 
Table 8: Number of Mothers With Equal Intended Bequests and Equal Inter Vivos Transfers

\begin{tabular}{|l|r|r|r|}
\hline \multirow{2}{*}{ Bequests } & \multicolumn{3}{|c|}{ Inter Vivos Transfers } \\
Equal & Equal & Unequal & All \\
\cline { 2 - 4 } Pct. of row total & 135 & 659 & 794 \\
Pct. of sample & 17.0 & 83.0 & 100.0 \\
Unequal & 15.8 & 77.1 & 92.9 \\
\cline { 2 - 4 } Pct. of row total & 16 & 45 & 61 \\
Pct. of sample & 1.9 & 73.8 & 100.0 \\
All & 151 & 704 & 7.1 \\
\cline { 2 - 4 } Pct. of sample & 17.7 & 82.3 & 855 \\
\hline
\end{tabular}

Note: Based on "definition 1" of unequal bequests (see table 4). 


\section{Appendix}

Table A: Sample Selection Criteria

\begin{tabular}{|c|c|c|c|}
\hline & $\begin{array}{l}\text { Mature } \\
\text { Women }\end{array}$ & $\begin{array}{c}\text { Young } \\
\text { Women }\end{array}$ & $\begin{array}{c}\text { All } \\
\text { Women }\end{array}$ \\
\hline Number of women interviewed in 1999 & 2,467 & 2,900 & 5,367 \\
\hline No children in child roster & -349 & -520 & -869 \\
\hline Number of mothers & 2,118 & 2,380 & 4,498 \\
\hline Number of children & {$[7,721]$} & {$[6,551]$} & {$[14,272]$} \\
\hline Fewer than two children age 18 or older & -281 & -726 & $-1,007$ \\
\hline Number of mothers in baseline sample & 1,837 & 1,654 & 3,491 \\
\hline Number of children age 18 or older & {$[7,415]$} & {$[5,018]$} & {$[12,433]$} \\
\hline Existence of will unknown & -59 & -52 & -111 \\
\hline Report having no will & -744 & -938 & $-1,682$ \\
\hline Plan to leave nothing to children, or plan unknown & -33 & -27 & -60 \\
\hline Do not report intended division of estate & -17 & -3 & -20 \\
\hline Number of mothers in bequest sample & 984 & 634 & 1,618 \\
\hline Number of children age 18 or older & {$[3,612]$} & {$[1,880]$} & {$[5,492]$} \\
\hline Inter vivos transfer amount missing for all children & -292 & -160 & -452 \\
\hline Make no transfers to any children & -211 & -100 & -311 \\
\hline Number of mothers in inter vivos transfer sample & 481 & 374 & 855 \\
\hline Number of children age 18 or older & {$[2,279]$} & {$[1,352]$} & {$[3,631]$} \\
\hline Number of children with transfer data & {$[1,509]$} & {$[964]$} & {$[2,473]$} \\
\hline
\end{tabular}

